Printing the Middle Ages 
MATERIAL TEXTS

Series Editors

Roger Chartier Anthony Grafton

Joan DeJean Janice Radway

Joseph Farrell Peter Stallybrass

A complete list of books in the series is available from the publisher. 


\section{Printing the Middle Ages}

S IÂN E CHAR D

\section{$\overline{\text { PENN }}$}

University of Pennsylvania Press

Philadelphia 
All rights reserved. Except for brief quotations used for purposes of review or scholarly citation, none of this book may be reproduced in any form by any means without written permission from the publisher.

Published by

University of Pennsylvania Press

Philadelphia, Pennsylvania 19104-4112

Printed in the United States of America on acid-free paper

$\begin{array}{llllllllll}10 & 9 & 8 & 7 & 6 & 5 & 4 & 3 & 2 & 1\end{array}$

Library of Congress Cataloging-in-Publication Data

Echard, Siân.

Printing the Middle Ages / Siân Echard.

p. cm.- (Material texts)

Includes bibliographical references and index.

ISBN 978-0-8122-4091-7 (acid-free paper)

1. Books-History. 2. Printing-History. 3. Manuscripts, Medieval-Editing.

4. English literature-Middle English, 1100-1500-Criticism, Textual. 5. Literature, Medieval-Criticism, Textual. 6. Literature, Medieval-Appreciation-English-speaking countries. 7. Transmission of texts. 8. Bibliography, Critical. 9. MedievalismEnglish-speaking countries. I. Title.

Z4.E25 2008

$686.209-\mathrm{dc} 22$

2008010934 